\title{
EFFECT OF COOPERATIVE LEARNING MODEL NUMBERED HEADS TOGETHER (NHT) TYPE ON STUDENT LEARNING OUTCOMES IN SOCIAL SCIENCES SUBJECTS IN GRADE V ELEMENTARY SCHOOL
}

\author{
${ }^{*}$ Resty Fauziah ${ }^{1}$ and Maria Montessori ${ }^{2}$ \\ ${ }^{1}$ College Student Primary Education, FIP Universitas Negeri Padang, Indonesia \\ ${ }^{2}$ Civic lecture, FIS Universitas Negeri Padang, Indonesia \\ E-mail: restyfauziah157@gmail.com
}

*Corresponding Author, Received: November 12, 2018, Revised: December 10, 2018, Accepted: December 21, 2018

\begin{abstract}
The purpose of this study was to examine the effect of the Numbered Heads Together (NHT) Cooperative Learning Model on Student Learning Outcomes in Social Sciences Subjects of Class V Elementary School. The study population was all fifth grade students of SD 21 Cindakir Bungus Bay, Kabung Bay, Padang City. The study sample was a fifth grade student at SD 21 Cindakir Bungus Bay, Kabung Bay, Padang City. Data from research results are obtained from student learning outcomes tests. The results of the study indicate that there is an influence of the Numbered Heads Together type Cooperative Learning Model on social studies learning outcomes in class V SD 21 Cindakir Bungus Bay, Kabung Bay, Padang City
\end{abstract}

Keywords: Numbered Heads Together Models, Learning Outcomes

\section{INTRODUCTION}

Social science (IPS) is one of the subjects taught in Elementary School. Social studies learning at the elementary school level aims to prepare students as citizens who not only master the aspects of knowledged, but also skills, attitudes and values that they can use as the ability to solve personal problems. or social problems, as well as the ability to make decisions and participate in various community activities in order to become good citizens (Sapriya, 2009). Social studies learning is very important for students in their lives as citizens, individuals and as citizens. By learning IPS, students will be able to become good, democratic and responsible Indonesian citizens and be 
able to develop social skills that students really need to solve personal problems or social problems that they face in life in society or globally that always change at any time .

So that the expected social studies learning objectives above can be achieved well, ideally in the process of learning social studies in elementary schools, teachers are expected to be able to provide information relating to the environment in which the students are located. This is because if someone does not understand the environment, it will be difficult to become a good citizen. Therefore, early on students must be prepared to have enough information about their environment, both what is happening, and what they will face (Isjoni, 2007).

In the implementation of social studies in classrooms, teachers are expected to be able to carry out social studies in an interesting and fun way. This is important to do in order to increase students' enthusiasm and interest in social studies (Hermon and Dalim, 2005; Hermon and Dalim, 2006). But the reality that is now happening, according to Purmiati (2012) In social studies subjects, most teachers choose conventional learning activities. The teacher explains with the lecture method then students write it in a notebook. As a result, many students are passive and bored with social studies learning activities. Many students feel less interested in social studies subjects and tend to be absorbed in their own activities regardless of the teacher's explanation.

The above facts also occur in class V of SD 21 Cindakir Subdistrict Bungus Teluk Kabung, Kota Padang. Based on the observation of the writer and question and answer with the fifth grade teacher of SD 21 Cindakir Subdistrict Bungus Teluk Kabung, Padang on March 6-24, 2018 the author found several problems in the social studies learning process. These problems are 1) many students who do not make their homework, 2) students tend to be passive in learning both classical and group learning, 3) when the learning process takes place there are many students who go out of class, 4) when the teacher explains the lesson ahead the class is seen students talking with friends, 5) student learning outcomes are low.

This means that there are still many students who have not obtained learning outcomes beyond the minimum completeness criteria set by each school where the 


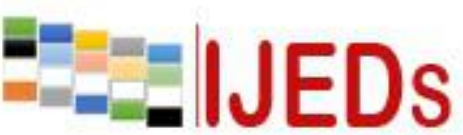

http://ijeds.ppj.unp.ac.id/index.php/IJEDS

researcher made observations, namely 75 . This indicates that the learning that has been carried out has not been successful. The use of an inappropriate learning model as one of the low causes of student learning outcomes is also supported by Susanto's opinion (2014) revealing factors that influence student learning outcomes, one of which is the model of presentation of subject matter conducted by the teacher.

The low student learning outcomes need to be addressed immediately. Because, if not immediately addressed it will have a negative impact on the success of the next student. one of the efforts that can be done by the teacher to overcome these problems is by using the right learning model that can solve the problem that is able to improve student learning outcomes. One model that is suitable to overcome the problem above according to the author is Numbered Heads Together (NHT) type cooperative learning.

This model is one of the types of ccooperative learning models that certainly pay close attention to the heterogeneity of students in the division of groups. In addition, the use of this model in learning is also able to create a fun learning process for students, able to deepen students' understanding of the material being studied, improve student learning achievement, increase student activity, self-confidence and motivation in learning, and be able to develop a sense of desire know students about teaching material, and as a good effort in training students' responsibilities in group discussions (Kurniasih and Berlin, 2015).

This model in its implementation uses numbers as its trademark. The numbers are given to each study group with the number of members of the group. However, each student in one group gets a different number but has the same number as the other group. Giving this number is to create fun learning for students (learning while playing) and at the same time as a form that all students have responsibilities in their groups. Because later every student in the MM group has a different task than his group friends. Besides that, the numbers will also be called randomly to answer the results of the group discussion in front of the class. By calling random numbers it is expected that each student truly understands the results of the group discussion and of course increases their understanding of the material presented so that it influences the improvement of learning outcomes. 


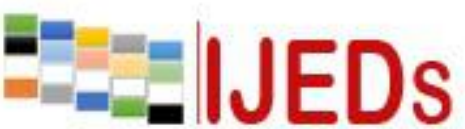

http://ijeds.ppj.unp.ac.id/index.php/IJEDS

The influence of the application of this model on student learning outcomes in the learning process is also supported by the results of research conducted by Febiliyanti, et al (2014). The results of the study indicate that there is a significant effect of using the Numbered Heads together type Cooperata learning model on student learning outcomes in science subjects. Furthermore, the results of research conducted by Santiana, et al (2014) also showed that the use of the Cooper model of Numbered Heads together learning had a positive effect on student learning outcomes on Mathematics subjects.

\section{METHOD}

This research is quasi-experimental research to reveal cause and effect occupancy by involving control groups in addition to the experimental group (Sugiyono, 2012). The design of this study uses the nonequivalent posttes only control group design pattern (Lestari and Mokhamad, 2015). This research was conducted in the fifth grade of SD 21 Cindakir Subdistrict Bungus Teluk Kabung, Kota Padang in the academic year 2018/2019. The research subjects were 44 students divided into 22 experimental class students and 22 control class students. The instrument used is two, namely the test of student learning outcomes. Instruments in the form of instruments in the form of tests are used to obtain data about student learning outcomes. The data analysis technique used is the t-test.

\section{RESULTS AND DISCUSSION}

Testing the second hypothesis in this study also uses the t-test. The t-test was carried out on the posttest data. T-test. Based on the results of the $t$ test on the posttest results shown by the table, the tcount is 4.021 , while $t$ table $=2.0189$. It can be concluded that $\mathrm{H} 1$ is accepted because of tcount $>t$ table. Thus it can be concluded that there are differences in student learning outcomes after being taught with the Numbered Heads Together (NHT) type Cooperative Learning model in the experimental class and student learning outcomes taught with conventional learning in the control class. 
The results of testing the second hypothesis revealed that the learning outcomes of experimental class students taught using the Cooperative Learning model of Numbered Heads Together (NHT) were higher than the learning outcomes of the control class students taught with conventional learning. This can be seen from the average learning outcomes of students taught with the Cooperative learning model The Numbered Heads together type is 85.2 or higher than the average learning outcomes in students taught by conventional approaches with a mean of 77.3.

This study has revealed that the Cooperative learning model of Numbered Heads together type has succeeded in influencing student learning outcomes in social studies learning. This success is because this model has learning steps that can involve students actively in learning both individually and in groups. This model in its implementation uses numbers as its characteristic learning.

Numbering used in implementing learning not only creates pleasant learning but also indicates that students have responsibilities in their groups. Because later every student in the MM group has a different task than his group friends. Besides that, the numbers will also be called randomly to answer the results of the group discussion in front of the class. By calling random numbers it is expected that each student truly understands the results of the group discussion and of course increases their understanding of the material presented so that it influences the improvement of learning outcomes.

The above expression is also reinforced by the opinion of Kurniasih and Berlin Sani (2015) which explains that the cooperative learning model of Numbered Heads Together can improve student learning achievement, able to deepen students' understanding and be able to practice responsibility. Furthermore, Siomin (2014) also stated that the use of cooperative learning Numbered Heads type in learning has several advantages, that is, each student becomes ready, can discuss seriously, clever students can teach students who are less intelligent, occur intense interaction between students in answering questions, and no students dominate in groups because there are limiting numbers.

The expert phrase above is also in line with what the researchers found when the study took place. During the learning process taking place in the experimental 
class using the cooperative learning model of Numbered Heads, students in the experimental class had an attitude that strongly responded to what the teacher said because learning began with a pleasant learning process. Furthermore, student activities in learning also look very good. All students look enthusiastic and active in learning. This is because each student in his study group has a different task. So this makes it possible for no student not to work in his study group. Seriousness and active involvement of student students in learning automatically increases students' knowledge of the subject matter being studied and certainly has an impact on improving their learning outcomes.

Unlike the students who were taught the cooperative learning model Numbered Heads. Students taught with conventional models in the control class are more passive in learning. This is because learning is more dominated by lectures, question and answer and assignments. At the time of the implementation of learning, some students were quite responsive to the questions posed by the teacher and student learning outcomes also increased, but the increase occurred less than the experimental class using the Cooperative Learning Numbered Heads Type. This is because the learning patterns used are less fun for students. According to Kurnia, Degeng, and Soetjipto (2017) if the learning process only uses conventional methods and models, the learning activities that occur tend to be passive and have an impact on the low student learning outcomes.

Based on the description above, from the results of research findings and data analysis that has been carried out it can be concluded that there are differences in student learning outcomes taught using cooperative learning models Numbered Heads Together with conventional learning. In addition, the results of the study used a cooperative learning model Numbered Heads Together also strengthened the results of previous studies conducted by previous researchers about the use of cooperative learning Model Numbered Heads Together, such as research conducted by Febiliyanti et al (2014). The research results of Febiliyanti et al (2014) which showed that there was a significant effect of using the Numbered Heads together type Cooperative learning model on student learning outcomes in science subjects. Furthermore, the results of Santiana's research, et al. (2014) also show that the use of 


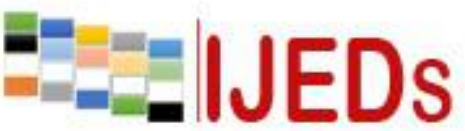

http://ijeds.ppj.unp.ac.id/index.php/IJEDS

the Cooper model of Numbered Heads together learning has a positive effect on student learning outcomes on Mathematics.

\section{CONCLUSIONS}

The conclusions of this study are the learning outcomes of students taught using the Cooperative learning model Numbered Heads together type are higher than the learning outcomes of students who are taught using conventional learning in social studies subjects in grade $\mathrm{V}$ elementary school. Based on the findings obtained in this study, suggestions 1) For teachers can apply the Numbered Heads together type of Cooperative learning model in social studies learning better, so as to create a better learning process, 2) For school principals to can provide guidance to teachers to understand the application of the Numbered Heads Together type Cooperatave learning model in the classroom through training, seminars, or workshops. by researchers.

\section{REFERENCES}

Febilitanti. 2014. Pengaruh Model Pembelajaran Kooperatif Tipe NHT (Numbered Heads Together) Terhadap Hasil Belajar Siswa Kelas XI IPA SMA Negeri 1 Dolo Pada Materi Pelajaran Kimia Koloid. J. Akad. Kim volume 2 nomor 2. ISSN 23026030

Hermon, D and Y. Dalim. 2005. Penggunaan Media Audio Visual untuk Meningkatkan Kreatifitas Belajar. Jurnal Pembelajaran. Vol. 28. Issue 3. p. 266-276

Hermon, D and Y. Dalim. 2006. Penerapan Kuliah Lapangan untuk Meningkatkan Hasil Belajar Mahasiswa. Forum Pendidikan. Vol. 28. Issue 3. p. 156-161

Isjoni. 2007. Pendekatan Pembelajaran IPS di Pendidikan Dasar. Bandung: Falah Production

Kurnia, N., Degeng, I. N. S., and Soetjipto, B. E. 2017. The implementation of find someone who and two stay two stray models to improve students' self-efficacy and social studies learning outcomes, IOSR Journal of Research \& Method in Education (IOSR-JRME), 7 (3), 66-70.

Kurniasih, I and B. Sani. 2014. Ragam Pengembangan Model Pembelajaran. Jakarta: Kata Pena.

Lestari, dan Mokhammad. 2015. Penelitian Pendidikan Matematika. Bandung : Refika Adimata 
Purmiati. 2012. Pengaruh Model Pembelajaran Kooperatif Tipe Numbered Head Together (NHT) terhadap Motivasi Berprestasi dan Hasil Belajar IPS pada Siswa Kelas V SD. e-Journal PGSD Universitas Pendidikan Ganesha Jurusan PGSD Vol: 3 No: 4 Tahun: 2016

Sapriya. 2009. Pendidikan IPS : Konsep dan Pembelajaran. Bandung: Rosdakarya Susanto, A. 2014. Teori Belajar dan Pembelajaran. Jakarta: Kencana

Santiana, dkk. 2014. Pengaruh Model Pembelajaran Kooperatif Tipe Numbered Heads Together (NHT) Terhadap Hasil Belajar Matematika Siswa Kelas V Sekolah Dasar Di Desa Alasangker. e-Journal PGSD Universitas Pendidikan Ganesha Jurusan PGSD Vol: 4 No: 1 Tahun: 2014 